\title{
The Inner Experience of Living Matter
}

\section{Bataille and dialectics}

\author{
Sørensen, Asger
}

Document Version

Final published version

Publication date:

2006

\section{License \\ CC BY-NC-ND}

Citation for published version (APA):

Sørensen, A. (2006). The Inner Experience of Living Matter: Bataille and dialectics. Department of Management, Politics and Philosophy, CBS.

Link to publication in CBS Research Portal

\section{General rights}

Copyright and moral rights for the publications made accessible in the public portal are retained by the authors and/or other copyright owners and it is a condition of accessing publications that users recognise and abide by the legal requirements associated with these rights.

Take down policy

If you believe that this document breaches copyright please contact us (research.lib@cbs.dk) providing details, and we will remove access to the work immediately and investigate your claim. 
The Inner Experience of Living Matter. Bataille and dialectics. Asger Sorensen

WP 2/2006 
MPP Working Paper No. 2/2006 (C)

March 2006

ISBN: 87-91839-14-9

ISSN: 1396-2817

Department of Management, Politics and Philosophy Copenhagen Business School

Porcelænshaven 18A

DK-2000 Frederiksberg C

Phone: +4538153630

Fax: $\quad+4538153635$

www.mpp.cbs.dk 
Asger Sørensen

The Inner Experience of Living Matter.

Bataille and dialectics.

Like many left-wing intellectuals in the twentieth century, Georges Bataille made Hegel the main point of reference for discussions of dialectics, citing his Phenomenology of Spirit in particular. Following a quite normal path from political-theoretical discussions within various left-wing groups to discussions of Hegelian dialectics, Bataille, however, is distinguished by belonging to a small and very privileged group of French thinkers. Not only did he attend the famous lectures of Alexandre Kojève in the 1930s and followed his extensive commentaries on the Phenomenology, he was also able to discuss the issues raised there with Kojève himself, since he very soon became part of the inner circle together with, among others, Jacques Lacan and Raymond Queneau. Bataille remained in contact with Kojève, he wrote extensively on Hegel, and their philosophical discussions went on until the very end of Bataille’s life.

Despite this, Bataille is today mostly associated with the kind of thinking that rejects the idea of dialectics as such. This impression is due primarily to Michel Foucault and Jacques Derrida, who both praised Bataille in the 1960s, first, for giving voice to a non-dialectical philosophical language and, second, for stating an alternative to Hegel's dialectics, which had allegedly reduced thinking to labour and closure. Since then very few philosophers have actually discussed dialectics and the relationship between Hegel and Bataille in any detail. This article is a contribution to filling this gap in the literature and thereby adding to the 
understanding of both dialectics as such and the thinking of Bataille.

First, Foucault's and Derrida's employment of Bataille in the critique of dialectics is presented as based on a conception of dialectics that is not shared by Bataille (I.). Instead, the dialectics of Bataille must be understood together with his peculiar epistemological position (II), and his materialist ontology, which extends the scope of dialectics beyond conscious being and history (III.). Bataille’s dialectical ontology does also extend the concept of desire and this gives another constitutional logic for self-conscious being (VI.). The conclusion is that Bataille's dialectics is related to that of Hegel in a way that distinguishes it from most modern dialectics by totalizing dialectics even more than Hegel, admitting both nature and the original human consciousness to have a history as well as humanity, but without the idea of one determinate end of history. Bataille's dialectics can be said to be the result of a determinate negation of Hegel, which made him one of the few non-Marxists in the 20th century who maintained and positively endorsed a totalizing metaphysical concept of dialectics. Including reality as such within the scope of dialectics in an even wider sense than Hegel, however, makes it very difficult for Bataille positively to recommend a specific course of political action (V.).

\section{Critique of dialectics}

To the young Foucault, criticizing Hegel was not just a matter of denying the widely accepted conception of history as collective human progress, nor of negating Kojève’s idea of communism as "the end of history"; like the classical positivists, he wanted to do away with 
all varieties of dialectics, metaphysics and speculative philosophy, and it is for this task that he employs Bataille. In the now classic article about Bataille from 1963, “A Preface to Transgression” Foucault claims that the language of philosophy is linked "beyond all memory (or nearly so) to dialectics" (Foucault 1963, p. $759(1998, \text { p. } 78)^{1}$ ), and a critique of dialectics is therefore a critique of philosophy as such.

Foucault construes "dialectical thought" as "the experience of the contradiction" (1963, p. 754 (1998, p. 72)), and what he praises in the thinking of Bataille is what he conceives as the attempt to break with "the sovereignty of the philosophizing subject", to insert a "fracture", which can develop "the form of a non-dialectic philosophical language" (p. 766 (p. 84)), "a language that speaks and of which he is not the master" (p. 760 (p. 79)). To such a "mad philosopher" "the philosophical language proceeds as if through a labyrinth", in the middle of "the transgression of his being as philosopher" (p. 762 (p. 80)). A transgression is given by inner experience and cannot as such be accessed by transcendental analysis or "dialectical movement" and is best described as a "non-positive affirmation" (p. 756 (p. 74)) and, like Nietzsche, Bataille's thought is "a critique and an ontology" that "understands both finitude and being" (p. 757 (p. 75)). According to Foucault, Bataille introduces a "philosophy of being speaking" in the place of a "dialectics of production", "a philosophy of the working man" (pp. 766 f. (pp. 84 f.)).

In spite of these radical claims about Bataille as contesting dialectics, and thus philosophy, as such, Foucault never went into detail about the concept of dialectics or the relations between been compared with authoritative translations when available. 
Bataille and Hegel. And even though Foucault's perspective is often recognized as being determined by Bataille, he only published one more text on Bataille (Raffnsøe 1994, p. 91; Habermas 1985, 279 f. (1987, p. 238 f.)), namely the very short presentation of Bataille’s Complete Works, which does not contain anything of philosophical substance (Foucault 1970).

Derrida's reading of Bataille, meanwhile, focuses precisely on the relationship to Hegel and dialectics. In his very influential article, “From Restricted to General Economy : a Hegelianism without reserve”, Derrida delivers a detailed, well argued and well substantiated analysis of Bataille that has become the last word for many thinkers on these matters. In Derrida's interpretation, Bataille also stages a radical critique of metaphysics that aims to do away not only with the idea of history, but with the ontological conception of dialectics as such. However, as Derrida correctly emphasises, "all of Bataille's concepts are Hegelian" (Derrida 1967, p. 26 (1978, p. 320)), and the negation of Hegel could therefore easily be called determinate or immanent, and thus dialectical.

Derrida, however, prefers to interpret Bataille’s thinking as “displacing” Hegel’s. According to Derrida, Bataille displaces the very conception of reality as a conscious being whose experience can be understood dialectically as an Aufhebung: "the speculative concept par excellence, says Hegel, the concept whose untranslatable privilege is wielded by the German language" (Derrida 1967, p. 29 (1978, p. 324)). "The Aufhebung is included within the circle of absolute knowledge, never exceeds its closure, never suspends the totality of discourse, work, meaning, the law etc." (p. 43 (p. 348)) To Derrida it is the same ontological logic that structures Hegel's conceptions of both history and experience, and Derrida identifies the 
dialectical logic with the totality of the ontological movement towards a determined end; that is, the accomplished movement of conscious being, which through the experience of determinate negation has lifted itself to a (pre-)determined result.

In doing this, Derrida makes Hegel's remarks, that the dialectical movement cannot find rest until the ultimate end and that the goal is as necessary for knowledge as the progression (Hegel 1807, p. 69 (1977, p. 51)) necessary for understanding dialectics. It is in this sense that he can denounce dialectics as a "closure". But this is an interpretation of dialectics that is not universally shared. Max Horkheimer, for example, reads the same remarks, not as a statement about dialetics, but as an expression of the non-dialectical, dogmatic aspect of Hegel's philosophy (Horkheimer 1935, p. 330 ff. (1993, p. 185 ff.)).

Like Foucault, Derrida makes Bataille his ally in a critique of dialectics as such, claiming that Bataille has "displaced" "the Hegelian logos" (Derrida 1967, p. 29 (1978, p. 325). However, in his reading Derrida of course also displaces Bataille, and towards the end of his reading he admits that this actually amounts to interpreting "Bataille against Bataille" (p. 43 (p. 348)). And the reason why this becomes necessary is simply that Bataille did not want to contest Hegelian dialectics in the same radical sense as Foucault and Derrida, because Bataille thought of dialectics in a different sense, namely in a sense close to that of Horkheimer. In this sense dialectics is a method that, as it has been put by Hans-Georg Gadamer, aims at grasping conceptually reality in motion, reality in change (Gadamer 1961, p. 13 ff.). Thus, whereas Foucault and Derrida had a concept of dialectics that implies system, totality, identity, end of history and thus closure, Bataille's concept of dialectics is inherrently openended. 
For Bataille, it is therefore possible to criticize Hegel and Kojève very strongly and still (or perhaps precisely therefore) consider his own thinking dialectical in the same sense as those criticized, i.e., those negated. Like Marx, Bataille states that his thought is the "opposite” of Hegel’s (Marx 1867/1890, p. 27; Bataille 1958, p. 615), but he immediately afterwards adds: "I only found myself there dialectically, if I may say so, Hegelically". As in the case of Marx the opposition of Bataille to Hegel must be understood dialectically, as a determinate negation, and Bataille can therefore, in the words of Queneau, be said to develop "a kind of anti-Hegelian dialectics" (Queneau 1963, p. 696).

This may come as a surprise to those familiar with the post-structuralist discourse and rhetoric that often surrounds Bataille. What may be even more surprising is that, though initially arguing for the now common position reserving dialectics only for the praxis of the changeable human world, Bataille keeps the possibility open for reintroducing nature into the realm of dialectics (Queneau 1963, p. 698), and, as we shall see, in his later work he actually revives and uses the totalizing concept of dialectics of Hegel and the traditional Marxists as basis for his understanding of reality as such. Bataille can thus be employed to negate various forms of closure but this did not lead him to denounce dialectics, quite the contrary.

\section{Experience and scientific knowledge}

Still, most twentieth-century readers of Hegel's Phenomenology, we recognize today, conceive of dialectics as the proper way to think of human reality in contrast to nature. By 
acknowledging the epistemological importance of this ontological distinction they implicitly adopt the traditional Aristotelian, non-empiricist way of understanding the relation between epistemology and ontology, i.e., that it is the structure of the being in question that determines the right way to understand that being, and that since human reality is differently structured than natural reality, we should relate differently to these two spheres intellectually.

This was also the case for the young Bataille and Queneau who criticized Engels' totalizing and reductive concept of dialectics by understanding dialectical development as part of the "real existence" of "every human being", namely as the "lived experience [expérience vécue]" of "negativity", i.e., something very close to Foucault's conception of dialectics as the experience of contradiction mentioned above. Such experience structures dialectics as a specific "method of thought", whose application to the "intelligence of nature" therefore is “risky” (Bataille \& Queneau 1932, p. 288 f. (1985, p. 113). ${ }^{2}$ To Bataille, however, accepting the metaphysical implications of this conception of dialectics is complicated by, first, his concept of 'inner experience', and, second, his unconditional materialism, and it is the gradual realization of this in his later work that makes the idea of a dialectics of nature reappear, although in another form than that conceived by Engels.

'Inner experience' is a development of the concept 'lived experience', by which Bataille

2 Although making claims about Hegelian dialectics, in 1932 Bataille had not studied Hegel as such (Bataille 1958, p. 615). It was only after following Koyré's and especially Kojève's lectures from 1933-39 that Bataille can be said to know the "right" Hegel (Queneau 1963, p. 700). From then on, when Bataille refers to Hegel, he is normally carefull to specify that he is discussing "the fundamentally Hegelian thought of Alexandre Kojève" (Bataille 1955, p. 326), as it is expressed in the translations and notes from lectures, editied and published by Queneau (Kojève 1947). However, as Derrida notes, when referring to the Phenomenology, Bataille is not consistent is his use of Kojève's translation (Derrida 1967, p. 27 (1978, p. 436)), which indicates that Bataille was familiar with Hyppolite's translation from 1941. 
wanted to express something like the German 'Erlebnis'. ${ }^{3}$ In The Inner Experience from 1943 he concentrates on the more dramatic aspects of inner experience like anxiety, ecstacy, and meditation, attempting with the form of the text to communicate the inner experience in a way which "corresponds to its movement" and to avoid just "a dry verbal translation" (Bataille 1943/54, p. 18). This becomes a kind of textual communication comprising aphorisms, poetry and prose, which Bataille takes as constitutive of a large textual project called The Atheological Sum after the Second World War.

The analysis of laughter, however, reveals to Bataille "a field of coincidences between the facts [donnée] of a common and rigorous emotional knowledge [connaissance] and the facts of a discursive knowledge" (1943/1954, p. 11), i.e., some objects of experience common to both scientific cognition and lived, inner experience. In Eroticism from 1957, Bataille can therefore attempt a more traditional discursive characterisation of the objects of inner experience, and of inner experience itself. Inner experience is then taken to comprise all those experiences that are not scientifically objectifying, i.e., the experience of art, erotics, laughter, etc. Science aims to describe reality as objects "from without", whereas Bataille wants to investigate reality experienced "from within", in the case of religion, for instance, not like the historian or sociologist, but as a theologist or a brahman. Inner experience can thus be communicated discursively, and Bataille also emphasizes that "the inner experiences is not given independently of objective views" (Bataille 1957, pp. 35 (2001, p. 31)). Such a discursive communication of inner experience and its relation to scientific knowledge constitutes Bataille's other big project, The Accursed Share, of which Eroticism was planned

\footnotetext{
3 The conceptual connection between these three terms is made explicit by Paul Ludwig Landsberg (1934, p. 178 f.), who was a close friend of Bataille in the 30'ies (Bataille 1935, p. $266 \mathrm{ff}$.$) .$
} 
to constitute volume two.

Like Hegels's concept of experience, Bataille’s inner experience is the experience of a consciousness. Bataille, however, makes a distinction between two different ways of experiencing reality, which do not depend on the object side of experience, but on the subject side. Though still within an ontological framework, these epistemological distinctions imply that the link between conscious being and reality as such becomes less definite for Bataille than for Hegel. It is therefore possible for Bataille to think the experience of reality, both human and natural, in two parallel, but each by themselves unified ways: scientific cognition and inner experience. It is within the latter that dialectics finds its place as the discursive translation of lived experiences of real negations, just as was already the case in Bataille's early discussion of dialectics mentioned above.

However, just as it is the case for Hegel in The Phenomenology, for Bataille dialectics includes the ontological movement of experience, which conscious being must go through in order to realize it-self as self-conscious. Still, there are crucial differences: one is that Bataille's concept of experience is more comprehensive than that of Hegel, another is that Bataille thinks of experiences as communicable in more than one way, and yet another is that when Bataille speaks of science, it is in a modern sense, as empirically based natural science, not in the classical philosophical sense used by Hegel.

To Aristotle, scientific knowledge (episteme) is knowledge of what necessarily is, which gets its validity from being structured by syllogistic logic (Eth.Nic. 1139b, 1140b). The idea of being as that which necessarily is, i.e., that being is eternal, unchangeable and structured by 
logic, whereas what changes, what becomes, or disappears, simply is not, neither in the ontological nor in the logical sense, goes back at least as far as Plato (Rep. 521d). Hegel, however, modifies the antique conception of being by accepting change as inherent in what is, thinking of life as the infinite movement-by-it-self.

For Hegel the dialectics of life is basic to the dialectics of being, it is life that, uplifted through experience, becomes absolute knowledge. Being is to Hegel always-already in-it-self conscious being, and as such being is only fully realized as uplifted to the conceptual movement-by-it-self of pure self-conscious being and spirit, Selbst-bewußt-sein and Geist, when the dialectical process of experience reaches its end in absolute knowledge. Reconstructing this movement conceptually as Hegel does in the Phenomenology is, as the original subtitle says, the Science of the Experience of Conscious-being, and this science leads to the Science of Logic. To Hegel science is in the end philosophy (Heidegren 1995, p. 345), which produces wisdom in the Aristotelian sense, i.e., intuitive insight in the principles of reality that becomes scientific knowledge by being well founded in reason (Eth.Nic 1141a).

As mentioned above, for Bataille science produces objective knowledge from without, that is, objectifying knowledge, not knowledge about what necessarily - or objectively - is. Science is not philosophy and does not deliver the only possible or the whole truth about reality. Bataille thus has a concept of science very different from that of Hegel, and, as Lyotard pointed out, the conflict between the two concepts is that with a Hegelian conception of scientific knowledge, modern empirical science cannot be said to deliver knowledge as such (Lyotard 1979, p. 63 f. (1984, p.37 f.)). It is, however, only with such a modern positivist conception of science that Bataille can legitimately divide what to Hegel in the end is only one. To sum up, 
first, that experience is more than (scientific) knowledge in both the senses mentioned, and that it as such can have other kinds of validity. Second, that with the modern idea of empirical science one can distinguish between a experience from without, which is objectifying, and an experience from within, which is not. Third, that such inner experiences can be communicated in various ways: discursively (or dialectically), simply verbally, or even without words, and all have their peculiar validity as forms of communication.

III. Matter and life

This complex epistemological position is, as mentioned above, coupled with a materialism that Bataille in his formative period declared to be "excluding all idealism" (1929, p. 180 (1985a, p. 16)). What is important is that the matter in question must not be understood as physical matter in the sense often employed by empiricists, i.e., as something that is fundamentally unchangeable, but can be moved in bulks and thus be understood primarily in terms of mechanics. Neither must matter be understood in the sense often employed by Marxists. Bataille distances himself from "giving matter the role that thought had" in Hegelian idealism, and thus making matter "a source of contradiction" (1930, p. 221 (1985b, p. 52)), determining the direction and end of the general history of man.

Bataille’s ideals of scientific knowledge are not taken from classical philosophy, nor from Newtonian physics or classical economy, but from twentieth-century scientific theories. Bataille's epistemology is developed on the basis of the new experiences of physics, biology, psychology and sociology, that is, sciences investigating and trying to grasp reality in change, 
and, in accordance therewith, Bataille's ontological materialism is inspired by thinkers such as Nietzsche, Freud, and Mauss. Matter is to Bataille first of all living matter, in natural and human beings, and excluding all idealism means that it "can only be defined as the nonlogical difference that represents in relation to the economy of the universe what the crime represents in relation to the law" (1933, p. 319 (1985c, p. 129)), i.e., the difference involved in a violation or a transgression. Matter signifies for Bataille the insubordination af nature in relation to culture, the continuous rebellion of life against all limits, in short, growth. ${ }^{4}$

Absolute knowledge about and in being is the only desirable goal for the kind of ideal selfconscious being that Hegel brings to an experience of it-self, but not necessarily for other kinds of conscious being. From the very beginning of Hegel's Phenomenology, consciousness is defined by the desire to become scientific knowledge of reality in the ancient sense. However, to a living conscious being, who like Bataille is having inner experiences both of the negation of its own material life and of the material transgression of the result of this negation, this goal can only appear as death. Bataille recognizes the essential link between ontology and epistemology, but conceives of both being and experience as essentially changing and constantly in motion.

Bataille's materialist dialectics of nature within the perspective of inner experience thus attempts to offer something that neither the ancient conception nor the Hegelian conception of dialectics could offer, namely, a comprehension of the material flux of life as a historical

4 To many liberal and left-wing rationalists such an organic way of understanding of reality in its totality is assumed to be irrational and as such in itself leading to fascism. Whatever can be said of this general line of reasoning, when it comes to Bataille, the charge is up against not only his explicit statements, personal sympathies, and organisational practice, but also the standard definition of fascism employed by political science (Sørensen 2001). 
process, i.e., grasping it with concepts that do not degrade it to, at best, a deficient mode of being, which must be negated in order to make consciousness appear. However, Bataille thinks of his dialectics as the result of a determinate negation of Hegel's, which of course maintains the Hegelian dialectic in the dialectics of Bataille as Moment.

In Eroticism, Bataille is mainly concerned with inner experiences, but he also describes "the physical condition" (Bataille 1957, p. 95 (2001, p. 94 )) of the objects of inner experience as "established by objective science" (1957, p. 19 (p. 13)), and this description is dialectical in the sense already mentioned, namely, as the attempt to grasp change conceptually. According to Bataille, non-sexual reproduction, which is the most primitive kind of reproduction, is the division of one cell into two. In the reproductive movement there is, as Bataille emphasises, a "passage", where the first cell dies as a discontinuous being, but "as it dies there appears a moment of fundamental continuity of the two new beings" (1957, p. 20 (p. 14)), and reproduction at this level cannot be distinguished from growth (1957, p. 96 (p. 95)).

Being cannot of course be considered conscious at this level, but when Bataille lets himself be guided by "our human inner experience" (1957, p. 104 (2001, p. 103)), the cell must also have an "experience from within" (1957, p. 100 (p. 99)), which in the moment of change is an experience of a "crises" (1957, p. 97 (p. 96)). Within a traditional ontology this moment is best described as contradictory in the Hegelian sense, being at one and the same time neither one nor many, but exactly in the process of both disappearing and becoming, both giving birth and dying, growing and reproducing, being both continuous and discontinuous. However, such a moment is part of a real material process, and such a process is for Bataille an evolution with a direction. The new continuity is the result of a determinate negation, which 
both annihilates and keeps the old continuity as Moment. The resulting continuity is both the same as the old continuity and different from it, both itself and not itself; that is, it remains conceptually contradictory, but also the result of an Aufhebung in the Hegelian sense.

In sexual reproduction the initial production of sexed cells is a reproductive division, but now distinguished ontologically from growth, and therefore not contradictory at the same level. At another level, however, this kind of division means that the same becomes even more different, i.e., that the ontological and logical contradiction within life becomes even more pronounced. The sexed cells of life are produced in different beings, and even when produced in the same particular being, they are not the same. For the reproduction to be complete, however, it is necessary that what is only living as differences again becomes one and the same, i.e. that two cells of different sex melt together and become one, that the fission is followed by a fusion and what was discontinuous becomes continuous. As Bataille expresses it, "a continuity establishes itself between the two to form a new being, originating from the death, the disappearance of the two separate beings" (1957, p. 20 (2001, p. 14)). Life’s continuity is established by the death of discontinuous beings, and this movement shows that "the lost continuity can be found again" (1957, p. 99 (p. 98)).

This scientific knowledge about asexual vs. sexual reproduction was of course not known to Hegel. Still in Hegel's speculative account of life also focuses on the contradictions of the fundamental movement of life. He describes life as essentially determined by an event, namely as when what does not rely on anything else, or is same-to-itself, das Sichselbstgleiche, divides itself: "The differences between dividing [Entzweiung] and becoming-same-to-itself [Sichselbstgleichwerden] are in themselves precisely only this 
movement of uplifting itself [sich Aufhebens]" (Hegel 1807, p. 126 (1977, p. 100-01) ${ }^{5}$. What is self-reliant as same-to-it-self is then in an opposition to the division, and as such not sameto-it-self, but in-it-self relying on something else, and thus divided. The result is to Hegel "the infinity or this absolute unrest of pure movement-by-it-self [Sichselbstbewegens]" (p. 126 (p. 101)).

This simple infinity, or the absolute concept, may becalled the simple essence [Wesen] of life, the soul of the world, the universal blood, which is omnipresent, without being driven by any difference, but still interrupted, which rather is itself every difference, just as their uplifted being [Aufgenhobensein], it pulsates within itself without moving, vibrates in itself without being restless. It is equal to itself [sichselbstgleich], for the differences are tautological; it is differences that are not. (Hegel 1807, p. 125 (1977, p. 100))

This movement must be considered so fundamental and objective that in a ontological sense it exists necessarily. According to Hegel life simply is, but its way of being is simultaneously disappearance and appearance, death and birth, one and many etc.. This way of being is best described as the ontologically necessary and constantly changing material identity of what is different and formally contradictory, in short simply as material flux. To Hegel life is in-it-self a "general fluidity", whose different "parts" become "independent" by negating "the universal substance", "the fluidity and continuity with it" (Hegel 1807, p. 136 f. (1977, p. 107)).

5 Unfortunately, the english translator of the Phenomenology has chosen to depart from "a rigid consistency in rendering Hegelian locutions” (Miller 1977, p. xxxi). It has therefore been necessary to correct the wording in most of the quotations used here. 
Negating is first a "consuming", and this maintains the independence of the being in question. This "immediate unity", however, passes from a stage of "immediate continuity" to be a "reflected unity", which is the "pure" or "simple I" (p. 138 f. (p. 108 f.)).

Whereas Bataille focuses on the reproduction of life as a material development with a result that can be thought of as an Aufhebung and therefore within the sphere of history, what is at stake here for Hegel is only the initial constitution of conscious being by the negation of life as such. Hegel does not make any distinction here between the reproductive structure of a complex sexual being in relation to life and that of primitive asexual cells; both pass in the reproductive act between being one and two, continuous and discontinuous. Higher as well as lower forms of life proceed through the process of fission and fusion, continuity and discontinuity. The only difference between primitive life and higher forms is apparently the number of necessary elements in the process of reproduction and the complexity of the ordering.

IV. Desire and conscious being

To understand what is at stake here, and how Bataille can be said to develop Hegel's dialectics beyond Hegel, it is necessary to be more detailed in the account of life and the initial constitution of the self. One can say that in Hegel's dialectics of life the ontologically necessary correlate of division and discontinuity must be attraction, and within the consciousness of one of the two sides such an attraction is experienced as a desire directed towards that which is different, i.e., the other or another. The human being is as self- 
conscious being constituted by the negation of life, which means that "self-consciousness is certain of itself only by the Aufheben of this other that presents itself to self-consciousness as independent life" (Hegel 1807, p. 139 (1977, p. 109)). If this desire is experienced as hunger, it is consciousness' desire to annihilate another independent living being, "consuming" (p. 137 (p. 107)) the other, and such an annihilation of another being Hegel calls "natural" or "abstract negation" (p. 145 (p. 114)). This is precisely the primary movement of selfconscious being, still only in-it-self and not yet for-it-self, namely the desire for an opposite, which is "a living thing" (p. 135 (p. 106)). Desire in this sense can therefore be considered a contradiction of life within the experience of consciousness: life giving birth to death. What in reality is one, self-conscious being-alive, develops into a contradictory opposition.

For Hegel, the problem for desire as consciousness is that satisfaction in it self makes the object of desire disappear, which leaves desire to look for a new object. However, regardless of whether desire is experienced from without or from within in the reproduction of life, it is not only directed towards nourishment, but also towards the other sex. The development of life towards higher forms is precisely expressed in this duality of desire. Whereas Hegel focuses on hunger, Bataille interprets desire primarily as the inner experience of sexual attraction. As such, desire naturally presupposes a difference; but, more importantly, it presupposes an opening up towards communication with another: "the passage from the normal state to that of erotic desire presupposes in us the relative dissolution of the being constituted in the discontinuous order" (Bataille 1957, p. 23 (2001, p. 17)). It should also here by pointed out that satisfaction is not an abstract negation in the case of erotic desire, but an event that leaves the object capable of being negated and thus of satisfying desire again. 
For Bataille, as for Hegel, desire must be considered the desire to become continuous with the other by negating its independency, to annihilate the other as (an)other. In relation to life independent continuous beings are discontinuous. Sexual activity must in this perspective be seen as the "critical moment of the isolation" (Bataille 1957, p. 101 (p. 100)), and this crisis is solved by the real continuity of the moments of sexual union. In a Bataillian perspective, however, this only makes desire even more contradictory. The desire of a being is directed towards a momentary union with another being that both annihilates and keeps the difference by uplifting it to a "momentary continuity" (1957, p. 103 (2001, p. 103)). Such a momentary Aufhebung of independence and isolation give, objectively speaking, birth to more life, that is, makes life as such grow, although the more we enjoy the act in it self the less we worry about the possible outcome, i.e., the children (1957, p. 103 (p. 102)).

Desire is necessary for the fusion of sexual reproduction and therefore for the growth of life, when first it has become sexualized; but desire is also a negation of life, creating contradictions within life at various levels. The discontinuity of life as experienced in desire forces every being to make distinctions and to chose in relation both to what to annihilate by consumption, and what to treat as attractive in the sexual sense. The necessity of choosing between the objects of desire introduces a pause, a temporal discontinuity that inhibits the continuous process of life, and a choice like this must be termed conscious in some rudimentary sense.

Conscious life is thus in itself a contradiction, and in an even more radical way than the contradictions at the unconscious level. As a contradiction conscious life appears within life itself, not as something anti-thetic coming from outside life, but exactly as the determinate 
negation of life by life itself. Such a consciousness of distinction and choice, however, demands justification, first in the simple form of reasons to make one distinction and not another, one choice instead of another, and later as full-blown subjective rationality, which claims to be in accordance with objective reason. This is the logic in "the passage of existence in-it-self [en soi] to existence for-it-self [pour soi]", where the animals "sentiment of it-self" becomes a "self-consciousness" (Bataille 1957, p. 100 (p. 99)).

In Hegel's account of life in the Phenomenology there is only movement and change, no development and no direction; history begins with the negation of life by conscious being and comes to an end when consciousness is realized as self-conscious being. With his concept of desire Bataille opposes Hegel's undifferentiated and ahistorical concept of life and introduce a development, both within the process of life's reproduction of it-self and in the evolution from asexual to sexual reproduction. This also transforms Hegel's idea of history as nothing other than the progression of a collective spirit through experience to become absolute knowledge, which however only begins with the birth of individual human consciousness in the initial negation of nature. As Queneau notes, Bataille conceives of the dialectics of nature as constituting "a sort of natural history" already in his early writings (Queneau 1963, p. 698). Bataille can be said to extend history back to the development of consciousness in nature, and can therefore also think of history as extending beyond the disappearance of man. In contrast to Hegel, Bataille thinks of life as historical, although this history has neither a beginning, nor any end, and this contrast reappears, when Bataille turns to the development of human consciousness.

Hegel's dialectics of being is objective in-it-self, as it is obvious in his conception of life, but 
the dialectical movement of conscious being only gets its validity for-it-self through conscious being's experience of its own development. This experience leads self-consciousbeing to Geist and absolute knowledge, where being comes to know itself in-and-for-it-self. To both Hegel and Bataille self-consciousness is specifically human, but whereas Hegel thinks of its constitution as an undifferentiated negation of life a such, Bataille in his perspective speaks of the passage from animal to man as a "dialectical process of development" (Bataille 1951, p. 36 (1993, p. 43)), that is, a material movement experienced as an inner experience of negation by being becoming human. Bataille notes that no one can know how this really happened in the natural history of human beings; what can be said with certainty is only how conscious life relates to reality as such, namely by negating it, by being moral and rational, by working, and by annihilating something else.

To Bataille this development is not just a matter of one negation and one Aufhebung of life, but a complex sequence of real material and historical negations, which together, through real inner experiences, finally lifts being up to become human. These negations are first of all the universal taboos in relation to death and reproduction, which anthropological studies have called our attention to. As Bataille says, "man is an animal which remains suspended [interdit] before death and sexual union" (1957, p. 53 (2001, p. 50)). It is not just a matter of the prohibition against incest, for instance, which to Bataille is just one particular "aspect" of "the totality of religious prohibitions" (1957, p. 54 (p. 51)). The point is that the confrontation with whatever is prohibited in this sense produces an inner experience, which cannot be caused only by what is experienced in itself. In a modern scientific perspective such a prohibition is "not justified" and therefore "pathological" as a "neurosis", but, as Bataille stresses, this objective knowledge "from without" does not make the experience disappear, 
and as seen "from within" such a prohibition can both be "global" and "justifiable" (1957, p. 40 (р. 37)).

To Bataille what is prohibited in the taboo is the "violence" of nature, and the human attitude is precisely the "refusal" (1957, p. 64 (p. 61)) of such a violence. Prohibitions are thus negations of nature as experienced from consciousness. Without such prohibition human beings would never attain "the clear and distinct consciousness [...] on which science is founded" (1957, p. 41 (p. 38)). The human "no" to natural violence, however, is never definitive. According to Bataille it is only a pause, “a momentary suspension, not a final standstill” (1957, p. 65 (p. 62)). The basic non-logical difference does not disappear, it just reaches a temporary unity, and this unity makes life's activity human, i.e., makes activity conscious and reasonable as poiesis and praxis. The resulting unity is not stable, but what Bataille would call a necessary impossibility. As such an impossibility, human life will break down again and again, not because of outer pressure, but because of the basic inner difference that cannot be annihilated, but keeps returning in new forms. It is not desire as such that breaks through civilization mechanically, but desire interpreted and thus transformed to a Moment of conscious being. In this form desire negates the basis of civilization, and it is in such acts of sovereignty that man transgresses the boundaries set by civilization.

\section{Conclusion}

If the conflict between the reasonable order of civilization and the subversive, violent pleasure of nature is understood theoretically as a logical contradiction it must be resolved, 
i.e., what was above described as the ontologically necessary contradiction in life as selfconscious being must be explained away,. A non-conflicting, i.e., a non-dialectical, solution can only consist in siding with one or the other, idealizing either a self-defeating critique of civilization as such, or a pure and therefore senseless negation of nature as a whole. Hegel chose the last solution, accepting in the end only being uplifted to reason, spirit and absolute knowledge.

This is what Horkheimer termed the dogmatic aspect of Hegel's philosophy. However, if dialectics is understood in the sense proposed by both Horkheimer and Gadamer, i.e., as the method employed in Hegel's Phenomenology as a way of grasping change, one can oppose both theoretically and practically almost any given social organization to be, as Herbert Marcuse expresses it, "in contradiction with its own truth" (Marcuse 1941, p. 51). Of course, these reasons must be specific, and the result of the negation will not be something entirely new ex nihilo, since truth, as Marcuse says, is "a real process that cannot be put into a proposition" (1941, p. 100). But Hegel's dialectics makes it possible to conceive of politics as a matter of reason and truth, that is, as society's reflective and autonomous organization of itself, and not just a matter how the ruling classes organize the distribution of power and wealth.

Hegel's dialectics makes it possible to claim that a real existing society has not realized itself as a society if it is not a just society because the very concept of society implies justice. The practical opposition of a conscious being against such an insufficiently realized (and thus untrue) society can be said to be a determined negation, and the dialectical movement that it 
provokes becomes a real experience to conscious being. The theoretical aspect of such an opposition happens within the existing consciousness and can as such be labeled immanent critique, both in the logical and ontological sense.

The existing solution, i.e., self-conscious being as we know it, is the result of an infinity of real negations and Aufhebungs, but it can always be negated itself by practical scepticism, by consciousness demanding a reason, which is why the existing solution is worth choosing. As Hegel has demonstrated, it is possible to criticise and oppose any particular way of organizing our social being politically, just as it is possible to change that organization quite radically, if only we can give reasons that are acceptable to those affected by the change, i.e., reasons which hold in relation to the yardstick of the social being in question. Scepticism demands an acceptable reason for the determinate negation, and the critique will therefore always be immanent.

However, even without the dogmatic aspect of Hegel's philosophy, dialectics thus understood in terms of theoretical reasoning, i.e., in terms of logic and ontology, might be considered inhuman. Instead, inspired by the dialectics of Bataille, one could understand the basic contradiction in and of human life as just a conflict, a tension inherent in human and social being as such, and as such an ontological condition that is dealt with - and thus solved practically every day. The point to discuss politically is therefore not whether we can dissolve what the dialectical tradition would call the contradictions of the existing solution and reach the truth of the social being in question. The contradictions are always-already solved practically, and the question is only how to make these practical solutions better. 
No society is completely homogenous, since any human being takes part in more than one social being, e.g., families, classes, subcultures, associations, etc. The social being is in constant motion and change, and man as a self-conscious being is in itself in conflict, constantly negating nature and culture in himself and outside, obeying the norms and transgressing them, working and enjoying life, alone and together, thinking and acting. The only thing that does not make sense in such a dialectical materialist perspective is to hope for and attempt to realize a fixed ideal of conscious social being, once and for all, a final and eternally valid solution.

And maybe this is the problem, namely, that Bataille's dialectics is so thoroughly atheist and materialist that it does not lend any ontological credit or epistemological validity to those pure ideals and values that we normally let ourselves be motivated by in politics, morality, and religion. Bataille’s dialectics allow for critique and improvements, but there is nothing in Bataille's materialism that attributes ideal meaning and validity to some individual actions; there is nothing unconditional and absolute worth dying for, since such ideal values are just death in a symbolic form, fixed solutions that negate life. Reality changes, but since it is difficult to give reasons for choosing between various lines of closure and action, the postponement and the pauses keep getting longer. Politics demands a negation of change in the form of a disciplined effort over time, and a disciplined organisation powerful enough to exercise authority, again over time. Revolts are always possible, but revolutions and reforms, that is, real political action require fixed goals and sometimes inhuman discipline, treating human beings almost like things. In relation to such demands, Bataille's materialist dialectics, his recognition of the validity of inner experience as such and his radical critique of authority, risk becoming a mystifying ideology for a world organized only by the market, since no long 
term political action, no persistent use of force, seem legitimate in Bataille's perspective.

To sum up, contrary to the views of Foucault and Derrida, Bataille is one of the few twentieth century philosophers, who have actually taken Hegel's totalizing concept of dialectics seriously, acknowledging the importance of consciousness for the process and developing it in a consistently materialist way. Bataille describes the processes of nature and human culture dialectically, without comforting himself with dreams and hopes of ideals of a harmony that history or experience will realize in the end. As such Bataille's dialectics makes it possible to criticize not just any given society, but any attempt to give social being a determinate form, any vision about the perfect society, and it is this anti-idealism that Foucault and Derrida perceive as a critique of dialectics.

This anti-idealism, however, is also a source of a great vagueness in Bataille's work when it comes to saying positively how society should be. For Bataille to believe in an ideal, which can demand a sacrifice of humanity, would mean that we must negate dialectics undialectically, willingly not accepting change, that is, changing change into rest, forming the identity of identity and difference, the unity in rest incorporating motion and change as Moments, as a conscious act accepting the unacceptable, believing the unbelievable, in spite of knowing all beliefs to be futile. Needless to say, this is not easy.

In short, with an epistemology and an ontology like Bataille’s, it is very difficult to believe in anything worth dying for. And that's a shame. The world is in need of political action that can confront the fundamentalist belief in the blessings of market economics with equally strong beliefs in human solidarity and the possibility of doing politics with respect for human reason. 
We may have to reject Bataille’s material dialectics, not in order to be able to criticize, but in order to believe in the possibilities of practical politics.

Literature

Aristotle: Nicomachean Ethics (Eth.Nic.) in The Complete Works of ..., Vol. 1-2, Princeton University Press, 1984, vol. 2, pp. 1729-1867.

Bataille, Georges:

-Euvres Complètes (OC), tome I-XII, Paris: Gallimard, 1970-88.

-"Matérialisme" (1929) in OC I, pp. 179-180 (AMaterialism@ (1985a) in Bataille 1985, pp. 15-16).

-"Le bas matérialisme et la gnose" (1930) in OC I, pp. 220-26 (ABase Materialism and Gnosticism@ (1985b) in Bataille 1985, pp. 45-52).

-"La notion de dépense" (1933) in OC I, pp. 302-320 (AThe Notion of Expenditure@ (1985c) in Bataille 1985, pp. 116-29).

-"Les Présages" (1935) in OC II, pp. 266-70.

-L'Expérience intérieure (1943/54) in OC V, pp. 7-234.

-L'Histoire de l'érotisme ('1951') in OC VIII, pp. 7-165 (The History of Eroticim in Bataille: The Accursed Share. Volumes II \& III, New York: Zone Books, 1993, pp. 11-191).

-"Hegel, la mort et le sacrifice" (1955) in OC XII, pp. 326-345.

-L'Érotisme (1957) in OC X, pp. 7-270 (Eroticism, London: Penguin, 2001).

-"Notice autobiographique" (1958) in OC VII, pp. 615-16.

-Visions of Excess. Selected Writings 1927-1939, Minneapolis:University of Minnesota Press, 
1985.

Bataille, Georges \& Raymond Queneau: "La critique des fondements de la dialectique hégélienne" (1932) in OC I, pp. 277-90 (AThe Critique of the Foundations of Hegelian

Dialectic@ in Bataille 1985, pp. 105-15).

Derrida, Jacques: "Un hégelianisme sans réserve", L'arc, nº 32, 1967, pp. 24-45 (AFrom

Restricted to General Economy: A Hegelianism without Reserve@ in Derrida: Writing and

Difference, London: Routledge, 1978, pp. 317-50 + 434-42).

Foucault, Michel:

-"Préface a la transgression", Critique, tome XIX, nº 195-196, 1963, pp. 751-769 (AA Preface to Transgression@ in Foucault: Aesthetics, Method, and Epistemology, London: Allan Lane, 1994, pp. 69-87).

-APrèsentation@ (1970) in Bataille OC I, pp. 5-6.

Gadamer, Hans-Georg: "Hegel und die antikke Dialektik" (1961) in Gesammelte Werke, Bd. 1-10, Tübingen: Mohr Siebeck, 1986/99, bd. 3, pp. 3-28.

Habermas, Jürgen: Der philosophische diskurs der Moderne, Frankfurt a.M.: Suhrkamp, 1985 (The Philosophical Discourse of Modernity, Polity Press, 1987).

Hegel, Georg Wilhelm Friedrich: Phänomenologie des Geistes (1807), Hoffmeister ed., Hamburg: Felix Meiner Verlag, 1952 (Phenomenology of Spirit, transl. by A.V. Miller, Oxford University Press, 1977).

Heidegren, Carl-Göran: Hegels Fenomenologi, Stockholm/Stehag: Brutus Östling Bokförlag Symposium, 1995.

Horkheimer, Max: "Zum Problem der Wahrheit", Zeitschrift für Sozialforschung, Jhg. IV, Hf. 3, 1935, pp. 321-64 (AOn the Problem of Truth@ in Horkheimer: Between Philosophy and Social Science, Cambridge, Mass.: MIT Press, 1993, pp. 177-215 + 404-06). 
Kojève, Alexandre: Introduction à la lecture de Hegel, Paris: Gallimard, 1947.

Landsberg, Paul Ludwig: Einführung in die philosophische Anthropologie (1934), Frankfurt a.M.: Vittorio Klostermann, 1960.

Lyotard, Jean-François: La condition postmoderne, Paris: Minuit, 1979 (The Postmodern

Condition: A Report on Knowledge, Manchester University Press, 1984).

Marcuse, Herbert: Reason and Revolution (1941), London \& New York: Routledge, 2000.

Marx, Karl: Das Kapital, Bd. 1 (1867/90) in Marx \& F. Engels: Werke, Bd. 23, Berlin: Dietz Verlag, 1962/1975.

Miller, A.V.: ATranslator’s Foreword@ in Hegel 1977, p. xxxi.

Plato: Republic (Rep.) in Plato: Collected Dialogues, Princeton University Press, 1961, pp. $575-844$

Queneau, Raymond: "Premières confrontations avec Hegel", Critique, tome XIX, nº 195-196, 1963, pp. 694-700.

Raffnsøe, Sverre: AGrænsens uomgængelige uomgængelighed. Grænsens problematik hos Bataille og Foucault@ in Renè Rasmussen \& Asger Sørensen (Ed.): Excesser - af og om Georges Bataille, Århus: Modtryk, 1994, pp. 91-115.

Sørensen, Asger: "Georges Bataille: At tage ved lære af fascismen: Mellem modstand og analyse" in M. Hviid Jacobsen et al. (Ed.): Tradition og fornyelse i sociologien, Ålborg Universitetsforlag, 2001, pp. 241-60. 